\title{
Quantitative study of the evolution of notified cases of Zika Virus and the relationship with rainfall indexes in the state of Rondônia
}

\author{
Estudo quantitativo da evolução dos casos notificados de Zika Vírus e a relação com \\ índices pluviométricos no estado de Rondônia
}

\author{
Aline Maricato da Silva ${ }^{1}$, Wesley Joventino Prati $^{2}$, Gisleive Góes da Silva Correia ${ }^{3}$, \\ Pamella de Oliveira Cunha ${ }^{1}$, Francisco Carlos da Silva ${ }^{*}$
}

\begin{abstract}
${ }^{1}$ Biologist, Lutheran University Center of Ji-Paraná (CEULJI / ULBRA), Ji-Paraná, RO; ${ }^{2}$ Academic of the Biological Sciences Course at Centro Universitário São Lucas Ji-Paraná (UniSL), Ji-Paraná, RO.; ${ }^{3}$ Biologist, State Secretariat of Education of Mato Grosso (Escola Estadual 13 de Maio), Porto Esperidião, MT; ${ }^{4}$ Biologist, PhD in Cellular and Molecular Biology Applied to Health, teacher of the Biological Sciences Course, Centro Universitário São Lucas Ji-

Paraná (UniSL), Ji-Paraná, RO.
\end{abstract}

\begin{abstract}
Introduction: the Zika Virus is a virus transmitted by the mosquito Aedes aegypti, which is of great medical importance because it causes numerous public health issues. Objective: describe the scenario of the number of probable cases of the Zika virus in the state of Rondônia from January 2016 to October 20, 2018, demonstrating the relationship between the evolutions of cases during the analyzed period with a climatic factor during the period (rainfall index). Methodology: the data collected for statistical analysis were acquired through epidemiological bulletins published by the Secretariat of Health Surveillance and by the Ministry of Health. The pluviometric data used in the study were acquired from the Meteorological Station of the Ouro Preto Experimental Station - ESTEX/OP (Comissão Executiva do Plano de Lavoura Cacaueira-CEPLAC/RO), located in the central region of the state of Rondônia. Results: the data showed a total of 1,107 probable cases of acute disease caused by the Zika virus in the period from January 2016 to October 20, 2018 in the state of Rondônia, with $89 \%$ of this total being recorded only in 2016, showing a relationship with the high rainfall rate that occurred in the same year in the state. Conclusion: after analysis, it is concluded that, there was a considerable number of probable cases of Zika Virus in the state of Rondônia, in addition, the data showed that during the analyzed period, there was a relationship between the evolution of new cases with the rainfall index in the region. Preventive measures must be adopted in order to minimize the number of new cases. The population's awareness of the mosquito's reproduction and development can be an alternative to be adopted by the public health sectors of the state.

Keywords: Amazon Region. Tropical disease. Aedes aegypti. Public health.
\end{abstract}

\section{Resumo}

Introdução: o Zika Vírus é um vírus transmitido pelo mosquito Aedes aegypti, que possui grande importância médica por causar inúmeros problemas de saúde pública. Objetivo: descrever o cenário do número de casos prováveis do vírus Zika no estado de Rondônia no período de janeiro de 2016 a 20 de outubro de 2018, demonstrando a relação entre a evolução dos casos durante o período analisado com um fator climático durante o período (índice pluviométrico). Metodologia: os dados coletados para análises estatísticas foram adquiridos através de boletins epidemiológicos publicados pela Secretaria de Vigilância em Saúde e Ministério da Saúde. Os dados pluviométricos utilizados no estudo foram adquiridos junto à estação meteorológica da Comissão Executiva do Plano da Lavoura Cacaueira - CEPLAC, localizado na região central do estado de Rondônia. Resultados: os dados demonstraram um total de 1.107 casos prováveis da doença aguda causada pelo Vírus Zika no período de janeiro de 2016 a 20 de outubro de 2018 no Estado de Rondônia, sendo $89 \%$ desse total registrado somente no ano de 2016 , demostrando relação com o elevado índice pluviométrico ocorrido nesse mesmo ano no estado. Conclusão: após análise, conclui-se que, houve um número considerável de casos prováveis de Zika Vírus no estado de Rondônia, além disso, os dados mostraram que durante o período analisado, houve uma relação entre a evolução de novos casos com o índice pluviométrico na região. Medidas preventivas devem ser adotadas com o objetivo de minimizar o número de novos casos. A conscientização da população sobre a reprodução e desenvolvimento do mosquito pode ser uma alternativa a ser adotada pelos setores de saúde pública do estado.

Palavras-chave: Região Amazônica. Doença Tropical. Aedes aegypti. Saúde pública.

\section{INTRODUCTION}

According to the World Health Organization, tropical

Correspondente/Corresponding: *Francisco Carlos da Silva - End: - E-mail: fcsbiologicalscience@gmail.com -Tel: (69) 99304-0074. diseases are still a major public health problem which affects countless countries, causing thousands of deaths annually (BRASIL, 2015; ROSÁRIO et al., 2017). They are characterized as infectious diseases of difficult prevention and treatment that occur almost strictly in the tropical and subtropical portions of the planet, being generally associ- 
ated with extreme poverty, precarious basic sanitation and mainly to the neglect of the pharmaceutical industry and government agencies (BRASIL, 2015; COSTA et al., 2017).

The fever caused by the Zika Virus is considered one of the tropical diseases with the highest incidence in the last years and has affected several countries and continents (COSTA et al., 2017). The symptoms last from a few days to a week and are similar to other arboviruses, such as dengue and chikungunya (BRASIL, 2015; COSTA et al., 2017).

In November 2015, an outbreak of microcephaly was described in Brazil, and was then attributed to congenital Zika Virus infection (FRANÇA et al., 2016). The congenital Zika syndrome is considered to come from an infectious disorder, which causes damages in the central nervous system (CNS) development and microcephaly (LINDEN et al., 2016). Studies performed in the Northeast detected the presence of the RNA from Zika Virus in samples collected from the amniotic fluid in pregnant women, the evidence for microcephaly was observed by ultrasonography exams (ROZETTI et al., 2017).

The Brazilian epidemic in 2015 stimulated an emerging need for scientific improvement regarding the diagnosis of Zika infection, awareness of the pathogenesis of the congenital syndrome, discernment of immune response mechanisms, antiviral production, and new vector control technologies (LIMA-CAMARA, 2016).

Based on this perspective, currently there is a need to connect available strategies and technologies as a vector control measure that considers compatible and effective regional characteristics aiming to reduce the mosquito infestations, and the incidence of arboviruses transmitted by them (ZARA et al., 2016).

Thus, the objective of this study is to describe the number of probable cases of infection caused by the Zika virus in the state of Rondonia, demonstrating the relationship between the evolution of the cases (increase or decrease) with the rainfall levels that occurred during the study.

\section{MATERIALS AND METHODS}

This is an ecological time series study that proposes to correlate the number of probable cases (reported cases, excluding already discarded cases) of fever by the Zika virus in the state of Rondônia between January 2016 and October 20, 2018. It was evaluated also, the pluviometric index in the state in that same period. Rondônia has an estimated population of 1,757,589 inhabitants, being the third most populous in the northern region, according to data from the Instituto Brasileiro de Geografia e Estatística (IBGE - Brazilian Institute of Geography and Statistics) (2018).

The data collected for statistical analysis were acquired through epidemiological bulletins published by the Secretariat of Health Surveillance and by the Ministry of Health. Therefore, the information published in the epidemiological bulletins used in this study were extracted from the Sistema de Informação de Agravos de Notificação - Online (Sinan Net - System of Information of Reported Injuries).

The rainfall data for the period from January 2016 to October 20, 2018 were provided by the Meteorological Station of the Ouro Preto Experimental Station - ESTEX/ $O P$ (Comissão Executiva do Plano de Lavoura CacaueiraCEPLAC/RO), located in the municipality of Ouro Preto do West, about $340 \mathrm{~km}$ from Porto Velho, state of Rondônia, in order to demonstrate the possible relationship between the number of probable cases and the rainfall index recorded in the period. The data were evaluated with support of Microsoft Excel (2016 for Windows ${ }^{\circledR}$ ) considering simple descriptive analysis through the expression of relative frequency.

\section{RESULTS}

The data obtained demonstrated a total of 1,107 probable cases of the acute disease caused by the Zika Virus between 2016 and 2018 in the state of Rondônia. The year 2016 was the one with the highest incidence of probable cases in the state, representing $89 \%$ of the total recorded in the analyzed period, occurring in the following years decreases in the records (Figure 1).

Figure 1 - Percentage of probable cases of infection caused by the Zika virus in the state of Rondônia between January 2016 and October 20, 2018.

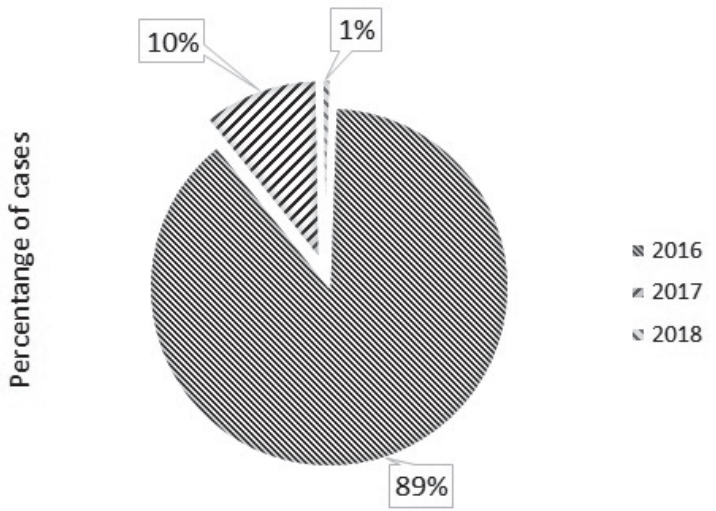

Fonte: Dados da pesquisa

He analysis of the relation between the climatological data and the number of cases recorded for the period of the survey showed a higher rainfall index in 2016, when there were a higher number of recorded cases. In the following years, there were lower rainfall indexes concurred by lower numbers of recorded cases (Figure 2). 
Figure 2-Relation between rainfall indexes and probable cases of the infection caused by Zika Virus in the state of Rondônia between January 2016 and October 20, 2018.

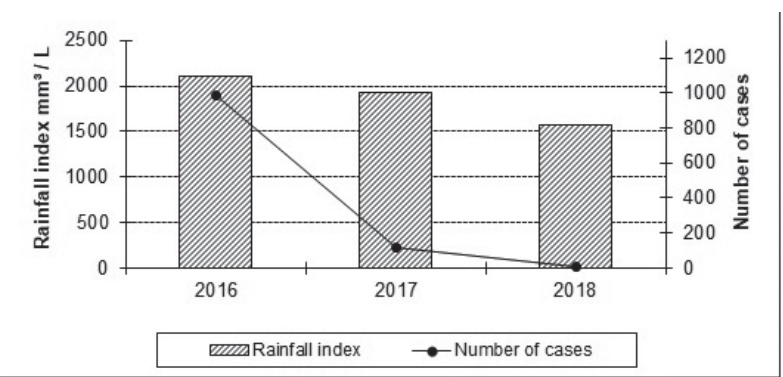

Data source: Meteorological Station of the Ouro Preto Experimental Station - ESTEX/OP (Comissão Executiva do Plano de Lavoura Cacaueira - CEPLAC/RO).

\section{DISCUSSION}

In this investigation, the predominance of probable cases of Zika Virus in the year of 2016 in the state of Rondônia was highlighted, coinciding with the period of greatest rainfall between the three years analyzed. The data found are similar to other studies performed in the Southeast and Northeast regions of Brazil, where occurred the epicenter of the epidemic started in 2016, the pointed theory is that the distribution of the virus in the other regions of the country is totally related to the internal migration process (LIMA-CAMARA, 2016; GARCIA, 2018). Besides, other factors favored the rapid spread of the virus, as example there is the intense emergence of mosquito breeding grounds due to the abundant rains in most regions of Brazil in 2016 (OLIVEIRA, 2017).

For Lima-Camara (2016), changes in the environment by anthropic actions, disordered urban growth, the process of globalization of international exchange and climate change are some factors facilitating the emergency and dissemination of human infectious diseases transmitted by vectors, as is the case of the propagation of the Zika Virus in the national and international scope.

According to a report from the Ministry of Health (2016), the increasing intensification of reported cases of Zika Virus in the last three years has triggered numerous social prevention campaigns regarding the development of the vector agent. Therefore, the epidemiological scenario of the Zika Virus in the state of Rondônia is considered relatively low when compared to other states in the North region, such as Amazonas, Pará and Tocantins, however, the results obtained through the statistics performed were higher than the total recorded in the entire South region of the country, making the state relatively potential in relation to the disease index (BRASIL, 2016; BRASIL, 2018).

As described by Oliveira (2017), the transmission of the Zika Virus to humans occurs basically through four different ways, however, the vector transmission form is highlighted, since the occurrence of contaminated vectors in urban areas has increased rapidly in the last decades, thus increasing the incidence of reported cases.
The propagation of the transmitter mosquito, A. aegypti, in urban areas is due to the numerous wastelands with accumulated rubbish and stagnant water in several neighborhoods, being the constant targets of breeding grounds of this vector (BRASIL, 2018).

Beyond the increase of the rainfall index, another influential situation is the rising temperature, which favors the proliferation of $A$. aegypti, because it increases the speed and development of the mosquito, these climatic conditions of temperature and rainfall are characteristic of the region, which favor the disease transmission (BRASIL, 2016).

The state of Rondônia, for being a relatively promising state to the development of the A. aegypti mosquito, vector of the Zika Virus, has a low number of studies aiming the clinical manifestation of the disease, it hampers the understanding of factors associated to the incidence of cases in the state, it is known, however, that in the national context, the intense migratory flow among countries with high rates of infected people is one of the factors responsible for the outbreak of the disease, which quickly manifested itself throughout the national territory (MANIERO et al., 2016).

From the analysis of this nucleus of thought, it is verified through the data statistics presented that the high index of cases reported in the state of Rondônia in 2016 may probably be related to the high rainfall index recorded in that same year, besides the climate of the state offer favorable characteristics to the development of the vector (MANIERO et al., 2016). Due to present a predominantly wet equatorial climate, the rain rates in the state are relatively high during a long part of the year, contributing to the emergence of breeding grounds in countless places, mainly in urban areas with precarious basic sanitation (BRASIL, 2016; BRASIL, 2018).

\section{CONCLUSION}

According to the data from this research, there were a total of 1,107 probable cases of acute disease caused by the Zika virus between the period of January 2016 to October 20, 2018 in the state of Rondônia. It was also possible to register that $89 \%$ of probable cases were registered in the year 2016, giving a relation with the rainfall index registered that same year in the state.

Thus, it is concluded that preventive measures must be developed with the objective of minimizing the number of new cases in the state of Rondônia, in addition, the methodology of awareness about the reproduction and development of the mosquito must be used more frequently and effectively among the public health sectors of the state.

\section{Acknowledgments}

This study was supported by the Research Support Program (PAP / UniSL) at Centro Universitário São Lucas Ji-Paraná, National Academic Cooperation Program in 
the Amazon (PROCAD-AM), National Council for Scientific and Technological Development (CNPq) and Coordination of Improvement of Higher Education Personnel (CAPES).

\section{BIBLIOGRAPHY}

$A L I$, S. et al. Environmental and Social Change Drive the Explosive Emergence of Zika Vírus in the Américas. PLoS Negl Trop Dis., v. 11, n. 2, p. e0005135, 2017. DOI: 10.1371/journal.pntd.0005135

BRASIL. Ministério da Saúde. Secretaria de Atenção à Saúde. Protocolo Clínico e D iretrizes Terapêuticas Síndrome de Guillain-Barré. Portaria no 1171. Brasília, 2015.

BRASIL. Ministério da Saúde. Secretaria de Vigilância em Saúde. Monitoramento dos casos de dengue, febre de chikungunya e doença aguda pelo vírus Zika até a Semana Epidemiológica 43 de 2018. Boletim Epidemiológico, Brasília, v. 49, n. 49, p. 1-14, 2018.

BRASIL. Ministério da Saúde. Secretaria de Vigilância em Saúde. Monitoramento dos casos de dengue, febre de chikungunya e febre pelo vírus Zika até a Semana Epidemiológica 49, 2016. Boletim Epidemiológico, Brasília, v. 47, n. 38, p. 1-10, 2016.

COSTA, J.M.B.S. et al. Painel estadual de monitoramento da infecção pelo vírus zika e suas complicações: caracterização e uso pela Vigilância em Saúde. Saúde Debate, Rio de Janeiro, v.41, n.3, p.316-328, 2017.

FRANÇA, G.V.A. et al. Congenital Zika virus syndrome in Brazil: a case series of the first 1501 livebirths with complete investigation. Lancet, London, v. 388, n. 10047, p. 891-897, 2016. DOI: 10.1016/S0140-
6736(16)30902-3.

GARCIA, L.P. Epidemia do vírus zika e microcefalia no Brasil: emergência, evolução e enfrentamentoIPEA: Brasília, 2018, p. 2368. (Instituto de Pesquisa Econômica Aplicada: Texto para discussão).

LIMA-CAMARA, T. N. Arboviroses emergentes e novos desafios para a saúde pública no Brasil. Revista Saúde Pública EPUB, Rio de Janeiro, v.50, n.36, p.1-7, 2016.

LINDEN, V.D. et al. Congenital Zika syndrome with arthrogryposis: retrospective case series study. BMJ, v.354, n.3899, p. 1-8, 2016. DOI: 10.1136/bmj.i3899.

MANIERO, V. C. et al. Dengue, chikungunya e zika vírus no brasil: situação epidemiológica, aspectos clínicos e medidas preventivas. Almanaque Multidisciplinar de Pesquisa, v.1, n.1, p. 118-145, 2016.

OLIVEIRA, W. A. Zika vírus: histórico, epidemiologia e possibilidades no Brasil. Revista Medicina e Saúde de Brasília, Brasília, v.6, n.1, p.93-10, 2017.

ROSÁRIO, M.S. et al . Doenças tropicais negligenciadas: caracterização dos indivíduos afetados e sua distribuição espacial. Revista Brasileira de Pesquisa e Saúde, Vitória, v.19, n.3, p.118-127, 2017.

ROZETTI, I. et al. Infecção pelo zika vírus e seu nexo causal com casos de microcefalia no Brasil: uma revisão da literatura. Anuário Pesquisa e Extensão Unoesc Joaçaba, 2: e13456, 2017.

ZARA, A.L.S.A. et al. Aedes aegypti control strategies: a review. Revista de Epidemiologia e Serviços de Saúde, v.25, n.2, p.391-404, 2016.

Submetido em: $31 / 07 / 2019$

Aceito em: 18/02/2020 